\title{
EKSTRAK DAUN PANDAN WANGI DAN ASAM JAWA TERHADAP DAYA REPELEN NYAMUK Aedes aegypti
}

\author{
Wintah $^{1 *}$, Kiswanto $^{2}$ \\ ${ }^{1}$ Fakultas Kesehatan Masyarakat, Universitas Teuku Umar Meulaboh \\ ${ }^{2}$ Fakultas Teknik, Universitas Teuku Umar Meulaboh \\ Jalan Alue Peuyareng Meulaboh Aceh Barat \\ Korespondensi : syuga_2006@yahoo.com
}

\begin{abstract}
There are some plants that have a distinctive odor and which smell is not liked by mosquitoes. one of the plants that is easily obtained and doubly beneficial for humans is pandan wangi leaves (pandanus amaryllifolius oxb) and tamarind leaves. The purpose of this study was to determine the effect of acidic extract of tamarind leaves on Aedes aegypti mosquitoes at various concentrations and the effect of persistence (length of time) of tamarind leaf extract applied on the test of Aedes aegypti mosquito, the method used is the experimental method, which is testing pandan wangi leaf extract and tamarind leaves with various concentrations on mosquito control. So the design used is a Completely Randomized Design (CRD). The results showed that essential oils of pandan wangi leaves and tamarind leaves had an effect on the repellent power of Aedes aegypti mosquitoes at 07.00-10.00 WIB and at 15.00-17.00 WIB. At the observations at 07.00-10.00 WIB, giving the most fragrant pandan leaves oil at concentrations of $50 \%$ and $90 \%$ with expulsion power of $89.7 \%$ and $91.3 \%$. Whereas in the observation at 15.00-17.00 WIB the use of essential oils of pandan wangi leaves expelled the mosquitoes at a concentration of $70 \%$ with an expulsion of $89.3 \%$, and the mosquito acid of the mosquitoes which was displaced by $89 \%$. The next suggestion is to use other plants besides pandan wangi and tamarind leaves which are not widely used to control mosquitoes, especially mosquitoes that can cause diseases such as Aedes aegypti.
\end{abstract}

Keywords: Pandan wangi, Tamarind, Repellent, Mosquitoes

\section{PENDAHULUAN}

Aceh Barat merupakan Kabupaten yang mempunyai potensi terjangkitnnya penyakit demam berdarah. Melihat topografi Aceh Barat adalah dataran rendah dengan tanah bergambut. Pada musim penghujan Kabupaten Aceh Barat sering terjadi banjir yang menggenangi setiap permukiman. Penyakit demam berdarah ini merupakan penyakit yang banyak menyerang penduduk di negara yang beriklim tropis. Hal ini dikarenakan, negara-negara tersebut memiliki kisaran suhu yang sama dengan kisaran suhu optimum bagi kehidupan nyamuk. Berbagai upaya pengendalian telah dilakukan dalam mengendalikan vektor Deman Berdarah Dengue (DBD), salah satunya yaitu dengan penggunaan insektisida kimia yang dianggap lebih efektif dalam menanggulangi vektor. Namun, penggunaan insektisida kimia yang terus menerus dalam jangka waktu yang lama akan menimbulkan resistensi terhadap serangga target.

Demam Berdarah Dengue (DBD), merupakan penyakit yang masih sering terjadi di berbagai daerah. Hal ini dikarenakan nyamuk penular dan virus penyebab penyakit ini hidup di sekitar kita. Pada tahun 1968, di Indonesia mulai ditemukan kasus penyakit Demam Berdarah Dengue (DBD) terutama di Jakarta dan Surabaya. Masalah ini merupakan masalah klasik, karena kejadiannya hampir disetiap tahun, khususnya di awal musim penghujan. Kondisi ini tidak hanya menimbulkan kerugian dalam bentuk materi 
berupa biaya pengobatan tetapi juga pengorbanan moril (korban jiwa) (Soedarmono 1988 dalam Kardinan, 2007).

Penyakit demam berdarah ini merupakan penyakit yang banyak menyerang penduduk di negara yang beriklim tropis. Hal ini dikarenakan, negara-negara tersebut memiliki kisaran suhu yang sama dengan kisaran suhu optimum bagi kehidupan nyamuk. Penyakit ini mulai ditemukan di Asia Tenggara setelah Perang Dunia II dan selama 15 tahun terakhir menjadi masalah kesehatan bagi masyarakat dunia (Hastowo et al., 1992 dalam Sanjaya dkk, 2006).

\section{PERUMUSAN MASALAH}

Ada beberapa tanaman yang memiliki bau yang khas dan yang aromanya tidak disukai oleh nyamuk. Tanaman-tanaman tersebut mengandung insektisida alami dari berbagai senyawa metabolik sekunder yang dihasilkannya, sehingga mengeluarkan bau yang khas dan tidak disukai oleh nyamuk. Salah satu tanaman yang mudah di dapat dan bermanfaat ganda bagi manusia adalah daun pandan wangi dan daun asam jawa. Karena di Aceh Barat banyak sekali ditemukan tanaman daun pandan wangi dan daun asam jawa yang tumbuh hampir di sepanjang jalan. Namun disetiap lokasi yang ditanami asam jawa tidak ada nyamuk. Melalui penelitian ini mencoba daya ektrak repelen dari daun pandan wangi dan daun asam jawa terhadap gigitan nyamuk Aedes Aegypti. Dari latar belakang diatas dapat dirumuskan permasalahannya adalah bagaimanakah daya tolak daun pandan wangi dan daun asam jawa terhadap nyamuk Aedes Aegypti pada berbagai konsentrasi.

\section{METODE PENELITIAN}

Dalam penelitian ini metode yang digunakan adalah metode eksperimen, yaitu menguji ekstrak daun pandan wangi dan daun asam jawa dengan berbagai konsentrasi terhadap pengendalian nyamuk. Sehingga rancangan yang digunakan adalah Rancangan Acak Lengkap (RAL) faktorial. Penelitian dilaksanakan di wilayah Aceh Barat Kecamatan Johan Pahlawan dan di Laboratorium Parasitologi Fakultas Kedokteran Hewan Alam Unsyiah.

\subsection{Bahan dan Alat}

3.1.1. Bahan

Bahan yang digunakan dalam penelitian ini adalah nyamuk Aedes aegypti, tikus, pakan tikus, gula pasir, alkohol $96 \%$, Akuades, kaca objek, kaca penutup, kapas, kertas sating, kertas tisu, label, dan batere.

3.1.2. Alat

Alat yang digunakan ;Aspirator, mikroskop, counter, hand Sprayer, ciduk, botol koleksi, nampan plastic, cawan petri, pinset, pipet, ovitrap, kandang nyamuk pemeliharaan, kandang nyamuk perlakuan uji repelen dan lampu senter.

\subsection{Perlakuan dan Rancangan Percobaan atau Kajian}

Penelitian meliputi dua jenis, biofikasi terhadap daun asam jawa yaitu sebagai repelen. Penelitian ini menggunkan metode rancangan acak kelompok (RAK) terdiri dari satu perlakuan control (tanpa perlakuan pengolesan repelen uji) dan 3 perlakuan bahan baku repelen (control positif, destilasi daun asam jawa). Pengamatan terdapat daya proteksi dilaksanakan masing-masing sebanyak 6 kelompok waktu pengamatan $(1,2,3,4,5$ dan 6 jam untuk pengamatan daya proteksi). 


\subsection{Parameter}

Identifikasi larva dari ovitrap dilakukan melalui pengamatan morfologi gigi sisir (comb) yang bergerigi pada segment abdomen ke-8 untuk menentukan larva Aedes aegypty, identifikasi dilakukan dengan mikroskop stereo dan dicocokkan dengan kunci identifikasi pada buku Aedes aegypty The yellow paper Mosquito.

\subsection{Penentuan Konsentrasi Minyak Atsiri}

Konsentrasi minyak atsiri dalam penelitian ini adalah sebagai berikut :

- Konsentrasi $0 \%=0 \mathrm{ml}$ minyak $+10 \mathrm{ml}$ aquades

- Konsentrasi $10 \%=1 \mathrm{ml}$ minyak $+9 \mathrm{ml}$ aquades

- Konsentrasi $30 \%=3 \mathrm{ml}$ minyak $+7 \mathrm{ml}$ aquades

- Konsentrasi $50 \%=5 \mathrm{ml}$ minyak $+5 \mathrm{ml}$ aquades

- Konsentrasi $70 \%=7 \mathrm{ml}$ minyak $+3 \mathrm{ml}$ aquades

\section{HASIL DAN PEMBAHASAN}

\subsection{Pengaruh Ekstrak dan Konsentrasi Minyak Atsiri Pandan Wangi dan Asam Jawa}

Hasil Penelitian dapat dilihat pada Tabel 1 dan 2. Dari Tabel 1 tersebut dapat dilihat rata-rata nyamuk yang hinggap pada tangan pada pukul $07.00-10.00$ WIB dan pukul 15.00 - 17.00 WIB menunjukkan bahwa ekstrak daun pandan wangi dan daun asam jawa dapat memberikan pengaruh yang berbeda-beda sebagai repelen nyamuk. Begitu juga dengan pengaruh pemberian konsentrasi ekstrak atsiri, berdasarkan hasil analisis terhadap pemberian konsentrasi ekstrak daun pandan wangi dan daun asam jawa menunjukkan perbedaan yang sangat nyata sebagai daya repelen nyamuk. Perbedaan pengaruh itu dapat dilihat pada Tabel 1 dan Tabel 2.

Tabel.1. Persentase nyamuk yang menempel ditangan pada pengamatan pukul $07.00-10.00 \mathrm{WIB}$

\begin{tabular}{|c|c|c|c|c|c|c|}
\hline \multirow{2}{*}{$\begin{array}{l}\text { Perlakuan } \\
\text { Spesies }\end{array}$} & \multirow[b]{2}{*}{ Konsentrasi } & \multicolumn{2}{|c|}{ Presentase } & & \multirow[t]{2}{*}{ Total } & \multirow[t]{2}{*}{ Rata-rata } \\
\hline & & I & II & III & & \\
\hline \multirow{6}{*}{$\begin{array}{l}\text { Pandan } \\
\text { Wangi }\end{array}$} & $0 \%$ & 40 & 45 & 46 & 131 & 43.7 \\
\hline & $10 \%$ & 24 & 23 & 21 & 68 & 22.7 \\
\hline & & & & & & \\
\hline & $30 \%$ & 21 & 14 & 17 & 52 & 17.3 \\
\hline & $50 \%$ & 15 & 18 & 13 & 46 & 15.3 \\
\hline & $70 \%$ & 9 & 10 & 7 & 26 & 8.7 \\
\hline \multirow{5}{*}{ Asam Jawa } & $0 \%$ & 34 & 35 & 30 & 99 & 33.0 \\
\hline & $10 \%$ & 22 & 19 & 15 & 56 & 18.7 \\
\hline & $30 \%$ & 30 & 29 & 27 & 86 & 28.7 \\
\hline & $50 \%$ & 15 & 15 & 12 & 42 & 14.0 \\
\hline & $70 \%$ & 11 & 8 & 9 & 28 & 9.3 \\
\hline Total & & 221 & 216 & 197 & 634 & \\
\hline
\end{tabular}


Tabel.2. Persentase nyamuk yang menempel ditangan pada pengamatan pukul $15.00-17.00 \mathrm{WIB}$

\begin{tabular}{|c|c|c|c|c|c|c|}
\hline \multicolumn{2}{|c|}{ Perlakuan } & \multicolumn{3}{|c|}{ Presentase } & \multirow[t]{2}{*}{ Total } & \multirow[t]{2}{*}{ Rata-rata } \\
\hline Spesies & Konsentrasi & I & II & III & & \\
\hline & $0 \%$ & 42 & 55 & 43 & 140 & 46.7 \\
\hline & $10 \%$ & 24 & 19 & 23 & 66 & 22.0 \\
\hline \multirow[t]{5}{*}{ Pandan Wangi } & $30 \%$ & 13 & 16 & 9 & 38 & 12.7 \\
\hline & $50 \%$ & 10 & 11 & 12 & 33 & 11.0 \\
\hline & $70 \%$ & 9 & 13 & 8 & 30 & 10.0 \\
\hline & $0 \%$ & 40 & 43 & 54 & 137 & 45.7 \\
\hline & $10 \%$ & 12 & 13 & 15 & 40 & 13.3 \\
\hline \multirow[t]{3}{*}{ Asam Jawa } & $30 \%$ & 13 & 16 & 9 & 38 & 12.7 \\
\hline & $50 \%$ & 12 & 13 & 8 & 33 & 11.0 \\
\hline & $70 \%$ & 8 & 10 & 14 & 32 & 10.7 \\
\hline \multicolumn{2}{|c|}{ Total } & 183 & 209 & 195 & 587 & \\
\hline
\end{tabular}

Tabel.3. Persentase nyamuk yang terusir dari tangan pada pengamatan pukul $07.00-10.00 \mathrm{WIB}$

\begin{tabular}{|c|c|c|c|c|c|c|}
\hline \multirow{2}{*}{$\begin{array}{l}\text { Perlakuan } \\
\text { Spesies }\end{array}$} & \multirow[b]{2}{*}{ Konsentrasi } & \multicolumn{2}{|c|}{ Presentase } & & \multirow[t]{2}{*}{ Total } & \multirow[t]{2}{*}{ Rata-rata } \\
\hline & & I & II & III & & \\
\hline \multirow{6}{*}{$\begin{array}{l}\text { Pandan } \\
\text { Wangi }\end{array}$} & $0 \%$ & 60 & 55 & 54 & 169 & 56.3 \\
\hline & $10 \%$ & 76 & 77 & 79 & 232 & 77.3 \\
\hline & & & & & & \\
\hline & $30 \%$ & 79 & 86 & 83 & 248 & 82.7 \\
\hline & $50 \%$ & 85 & 82 & 87 & 254 & 84.7 \\
\hline & $70 \%$ & 91 & 90 & 93 & 274 & 91.3 \\
\hline \multirow{5}{*}{ Asam Jawa } & $0 \%$ & 66 & 65 & 70 & 201 & 67.0 \\
\hline & $10 \%$ & 78 & 81 & 85 & 244 & 81.3 \\
\hline & $30 \%$ & 70 & 71 & 73 & 214 & 71.3 \\
\hline & $50 \%$ & 85 & 85 & 88 & 258 & 86.0 \\
\hline & $70 \%$ & 89 & 92 & 91 & 272 & 90.7 \\
\hline Total & & 779 & 784 & 803 & 2366 & \\
\hline
\end{tabular}

Tabel.4. Persentase nyamuk yang terusir dari tangan pada pengamatan pukul $15.00-17.00 \mathrm{WIB}$

\begin{tabular}{|c|c|c|c|c|c|c|}
\hline \multirow{2}{*}{$\begin{array}{l}\text { Perlakuan } \\
\text { Spesies }\end{array}$} & \multirow[b]{2}{*}{ Konsentra } & \multirow[b]{2}{*}{ I } & \multicolumn{2}{|l|}{ Presentase } & \multirow[t]{2}{*}{ Total } & \multirow[t]{2}{*}{ Rata-rata } \\
\hline & & & II & III & & \\
\hline & $0 \%$ & 58 & 45 & 57 & 160 & 53.3 \\
\hline & $10 \%$ & 76 & 81 & 77 & 234 & 78.0 \\
\hline \multirow[t]{5}{*}{ Pandan Wangi } & $30 \%$ & 87 & 84 & 91 & 262 & 87.3 \\
\hline & $50 \%$ & 90 & 89 & 88 & 267 & 89.0 \\
\hline & $70 \%$ & 91 & 87 & 92 & 270 & 90.0 \\
\hline & $0 \%$ & 60 & 57 & 46 & 163 & 54.3 \\
\hline & $10 \%$ & 88 & 87 & 85 & 260 & 86.7 \\
\hline \multirow[t]{3}{*}{ Asam Jawa } & $30 \%$ & 87 & 84 & 91 & 262 & 87.3 \\
\hline & $50 \%$ & 88 & 87 & 92 & 267 & 89.0 \\
\hline & $70 \%$ & 92 & 90 & 86 & 268 & 89.3 \\
\hline \multicolumn{2}{|c|}{ Total } & 817 & 791 & 805 & 2413 & \\
\hline
\end{tabular}




\subsection{Pengaruh Konsentrasi Ekstrak Daun Pandan Wangi Asam Jawa pada Pengamatan Pukul 07.00 - 10.00 WIB dan 15.00 - 17.00 WIB}

Berdasarkan Tabel 1 dan Tabel 2 dapat diketahui bahwa pemberian ekstrak minyak atsiri daun pandan wangi dan daun asam jawa berpengaruh sebagai daya repelen nyamuk. Hal ini juga disebabkan karena setiap spesies tanaman mempunyai kandungan zat atau bahan yang berbeda dan dengan prosentase kandungan zat yang berbeda pula. Daun pandan wangi mengandung bahan aktif (komponen utama) evodiamine dan rutaecarpine merupakan bahan aktif yang sangat tidak disukai nyamuk.

Hal ini sepeti yang telah diungkapkan oleh kardinan (2005), bahwa daun pandan wangi mampu menghalau nyamuk selama 6 jam dengan daya halau sebesar lebih dari $70 \%$.

Tanaman pandan wangi (pandanus amaryllifolius Roxb) mengandung insektisida botanic (alami) berupa saponin. Adanya senyawa saponin dalam daun pandan wangi telah dibuktikan oleh Rohmawati (1995) yang menyatakan bahwa kandungan kimia daun pandan wangi adalah senyawa pahit berupa polifenol, plavonoid, saponin, minyak atsiri, dan alkaloid. Adanya saponin dalam daun pandan wangi juga telah ditulis oleh Syamsuhidayat dan Jhonny (1991) yang menyatakan bahwa kandungan zat kimia dalam daun pandan wangi adalah alkaloid, saponin, plafanoid, tannin, dan polifenol.

Tanaman asam jawa yang biasanya dijadikan tanaman peneduh di jalan juga banyak digunakan sebagai tanaman bonsai untuk hiasan di rumah. Tanaman asam jawa mempunyai zat yang dapat digunakan sebagai repelen nyamuk.

Pada pengamatan pukul $07.00-10.00$ Wib menunjukkan pada konsentrasi $50 \%$ dan $70 \%$ berbeda nyata dengan kontrol dan konsentrasi 10\%, 30\%, 50\%. Hal ini dapat dilihat jumlah nyamuk yang terusir dari tangan pada konsentrasi $50 \%$ dan $70 \%$ paling banyak bila dibandingkan dengan yang lainnya.

Pada pengamatan pukul 15.00-17.00 Wib menunjukkan bahwa pada konsentrasi $70 \%$ tidak menunjukkan perbedaan yang nyata dengan $50 \%$. Sedangkan untuk konsentrasi $10 \%$ dan 30\% menunjukkan berbeda nyata dengan konsentrasi $50 \%$ dan $70 \%$. Semua keterangan diatas menunjukkan bahwa pemberian ekstrak dan konsentrasi yang berbeda dapat memberikan pengauh yang berbeda pula dalam mengendalikan nyamuk pada semua pengamatan.

Dari kedua jenis tanaman diatas menunjukkan bahwa dauan pandan wangi dan dauan asam jawa memiliki kemampuan yang hampir sama sebagai repelen nyamuk. Hal ini disebabkan karena kandungan zat yang hampir sama sebagai anti oksidan pengusir nyamuk.

Sesuai dengan indikator yang ingin dicapai yaitu peneliti mengetahui hubungan aromatik daun asam jawa terhadap nyamuk Aedes aegypti. Dari data hasil pengujian laboratorium didapatkan kesimpulan bahwa ekstrak daun asam jawa merupakan salah satu ekstrak yang dapat mencegah dan memiliki daya proteksi terhadap gigitan nyamuk Aedes aegypti.

Berdasarkan pembahasan diatas dapat dilihat bahwa ekstrak daun asam jawa ternyata dapat mencegah gigitan nyamuk Aedes aegypti karena memiliki daya proteksi terhadap gigitan nyamuk tersebut. Semakin tinggi kandungan ekstrak daun asam jawa maka semakin tinggi pula tingkatan daya proteksi terhadap nyamuk 
Aedes aegypti. Oleh karena itu, penggunaan ekstrak daun asam jawa sebagai salah satu lotion nyamuk sangat tepat diterapkan di masyarakat Aceh Barat yang rawan kasus DBD dengan pertimbangan efektif, tepat guna, dan praktis.

\section{KESIMPULAN DAN SARAN}

\subsection{Kesimpulan}

Berdasarkan pembahasan diatas dapat dilihat bahwa ekstrak daun asam jawa dan daun pandan wangi ternyata dapat mencegah gigitan nyamuk Aedes aegypti karena memiliki daya proteksi terhadap gigitan nyamuk tersebut. Semakin tinggi kandungan ekstrak daun asam jawa maka semakin tinggi pula tingkatan daya proteksi terhadap nyamuk Aedes aegypti. Oleh karena itu, penggunaan ekstrak daun asam jawa sebagai salah satu lotion nyamuk sangat tepat diterapkan di masyarakat Aceh Barat yang rawan kasus DBD dengan pertimbangan efektif, tepat guna dan praktis.

Berdasarkan hasil penelitian dan pengamatan terhadap pengaruh ekstrak minyak atsiri daun pandan wangi dan dauan asam jawa dengan berbagai konsentrasi yang berbeda terhadap daya repellent nyamuk, maka dapat disimpulkan:

5.1.1. Kemampuan ekstrak minyak atsiri daun pandan wangi dan daun asam jawa mempunyai pengaruh terhadap daya repelen nyamuk Aedes aegypti pada pengamatan pukul 07.00-10.00 WIB dan pukul 15.00-17.00 WIB.

5.1.2. Pada pengamatan pukul 07.00-10.00 WIB pemberian minyak atsiri daun pandan wangi paling banyak pada konsentrasi $50 \%$ dan $90 \%$ dengan daya usir sebesar $89,7 \%$ dan 91,3\%.Sedangkan pada pengamatan pukul 15.0017.00 WIB penggunaan ekstrak minyak atsiri daun pandan wangi mengusir pada konsentrasi $70 \%$ dengan daya usir sebesar $89,3 \%$, dan asam jawa nyamuk yang terusir sebesar sebesar $89 \%$.

\subsection{Saran}

Masyarakat dapat memanfaatkan ekstra asam jawa dan pandan wangi sebagi lotion anti nyamuk alami yang ramah lingkungan serta masyarakat mau membudidayakan pohon asam dan pandan wangi.

\section{DAFTAR PUSTAKA}

Kardinan, A. 2005. Tanaman Pengusir dan Pembasmi Nyamuk Vol II. Agro Media Pustaka. Jakarta.

Kardinan, A. 2007. Tanaman Pengusir dan Pembasmi Nyamuk Vol III. Agro Media Pustaka. Jakarta.

Rohmawati, E. 1995. Skrining Kandungan Kimia Daun Pandan serta Isolasi dan Identifikasi Alkaloidnya. Fakultas Farmasi, Universitas Gajah Mada. Jogjakarta.

Sanjaya A.W. Sudarwanto M, Soejoedono R.R, Purnawarman T, Lukman D.W, Latif H. 2007. Higiene Pangan. Departemen Ilmu Penyakit Hewan dan Kesehatan Masyarakat Veteriner. FKH-IPB. Bogor.

Syamsuhidayat, S.S., dan Johnny, R. H. 1991. Inventaris Tanaman Obat (I). Balitbangkes Depkes RI. Jakarta. 